Received: January 16, 2021 / Accepted: March 28, 2021 / Published online: July 2, 2021 The (C) Author(s) 2021. This article is published with open access at Academia Analitica

ORIGINAL SCIENTIFIC PAPER

UDC: 1 Descartes, R.

1 Spinoza, B.

\title{
Pantheistic Implications of Descartes' Epistemology and the Development of Spinoza's Metaphysics
}

\author{
Vladimir Lasica 1
}

\begin{abstract}
In this essay I intend to describe how Spinoza's pantheism represents a consistent development of Descartes' epistemology. While the fundamental starting point of Descartes' epistemology is the self-certainty, from which the existence of God is deduced, that eventually guarantees the existence of the world outside of the doubting subject, Spinoza's epistemology is based on the considerations of certain meanings, primarily of the meaning of 'substance.' Nevertheless, Spinoza's metaphysics, as we are going to see, expands on the main Cartesian notions. The main difference is that Spinoza continues Cartesian reasoning in a univocal manner, while Descartes restrains himself from challenging the tradition by insisting on equivocity of all meanings concerning God.
\end{abstract}

Key words: pantheism, epistemology, God, metaphysics

\footnotetext{
1 V.Lasica

Academia Analitica

Franje Račkog 1, 71000 Sarajevo, Bosnia and Herzegovina

lasoov@gmail.com
} 


\section{Introduction}

In his teaching about the infinite substance Spinoza was under the decisive influence of Descartes; he follows Cartesian conception of substance, attributes, modes, the idea that sensation is the source of error, the ambition to structure metaphysics in axiomatic mathematical way. But Spinoza is also under the influence of ancient Platonic and Neoplatonic tradition, the Renaissance Neoplatonism, but especially of medieval Jewish philosophy (Šajković, 1970, XXV$\mathrm{XXX}$ ). It is perhaps these influences that determined Spinoza's specific way of developing of Descartes' philosophy. In any case, once Spinoza's view is examined one can see that Descartes' central conception of 'substance' indeed has pantheistic implications, as the main definition of substance indicates that there can be only one substance - this is the central problem of the presented paper.

Although Descartes argues on the bases of clarity and distinctiveness that there are three substances, Spinoza notices that his conception essentially implies that the substance must be only one. According to Spinoza, clarity (which Descartes' method insists upon) of the meaning of 'substance' shows the oneness of substance, thus other two Descartes' substances, thought and extension, can only be its attributes. This idea is established at the very beginning of Spinoza's Ethics, thus the first part of this treatise is going to be our focus.

\section{Descartes' Theistic Metaphysics}

Central question in Descartes is how to reach certain knowledge at all, or how to acquire truth about things. If we accept medieval Aristotelian criteria of truth as "the equation of thing and intellect" or as "judgment conforms to the external reality" the legitimate question is how we reach this "equation" or "conformity," and how can we be certain that we reached it? Although "we have a moral certainty about these things, so that it seems we cannot doubt them without being extravagant," that is we have to accept the existence of all perceivable things for practical reasons at least, "when it is a question of metaphysical certainty, we cannot reasonably deny that there are adequate grounds for not being entirely sure about them" (Discourse, p. 38). Descartes tends to answer this question by formulating a method which eventually implies a sceptical challenge. The method is formulated in his treatise Discourse on the Method, and consists of four well known rules: 1) never to accept anything as true until acquiring evident knowledge that it its truth, or "to include nothing more in my judgements than what presented itself to my mind so clearly and so distinctly that I had no occasion to doubt it", 2) to 
divide every encountered difficulty into as many parts as possible in order to resolve them better, 3) to solve problems by beginning with the simplest and most easily known objects towards most complex and 4) to make complete enumerations and comprehensive reviews in order to be sure of leaving nothing out (Discourse, p. 19). The first rule is certainly the most important one. It represents Descartes' criteria of truth and the foundation of his methodological doubt (Petronijević, 1982, p. 135), as well as a general standard of clarity (Hatfield, 2014, p. 16). This methodological doubt represents a real sceptical chalenge to all possible knowledge, yet it distinct from sceptial approach in its main purpose: it is not set for the sake of doubting, but for the aim of reaching certainty (Discourse, p. 29), or as Descartes puts it differently: "I thought it necessary to... ...reject as if absolutely false everything in which I could imagine the least doubt, in order to see if I was left believing anything that was entirely indubitable" (ibid., p. 31). In short, Descartes is searching for "just one thing, however slight, that is certain and unshakeable," that is going to be his 'Archimedian firm point' from which he is going to 'shift' our knowledge into certainty (Meditations, II, p. 24).

The first problem encountered by applying Descartes' strict epistemological approach is the necessity to doubt in all knowledge acquired by the senses. Because it is clear that the senses are deceiving us occasionally, that is sufficient reason to doubt any information acquired in this manner (Discourse, pp. 31-32; p. 38; Meditations, I, p. 18). The next step is doubt in religious beliefs, so we should assume that there is a supreme being that in fact intends to deceive by creating false impressions in our mind (Meditations, I, pp. 21-22). Hence Descartes sums his doubt as follows:

"I will suppose then, that everything I see is spurious. I will believe that my memory tells me lies, and that none of the things that it reports ever happened. I have no senses. Body, shape, extension, movement and place are chimeras. So what remains true?" (ibid., p. 24).

Descartes answer represents a turning point of his philosophy, and according most historians, the turning point in history of philosophy in general: as long as subject doubts it thinks and as long as thinking it cannot doubt in its own existence; if I am thinking, therefore I exist, cogito, ergo sum, is the necessary true statement that cannot be doubted (Discourse, p. 32; Meditations, II, p. 25). Although this was well known point elaborated long before by Augustine of Hippo (354-430), ${ }^{2}$ Descartes is

\footnotetext{
2 According to Augustine of Hippo, if one is deceived, he must exist in order to be deceived (De civitate Dei, XI, 26). He also states:
} 
giving it a new dimension: a strict formulation from which metaphysics as philosophical discipline is found on the solution for the epistemological problem, instead on consideration of metaphysical notions (such as 'being', 'one', or 'good' as was the case during the medieval era). It is important to underline that Descartes' formula is not a sort of deduced knowledge, but one intuitively evident truth, and this is the exact reason why it cannot be questioned by sceptics (Petronijević, 1982, pp. 138-139), ${ }^{3}$ so not even a superior being cannot decieve us regarding this matter (Meditations, III, p. 36). This intuition shows us what is clear and distinct; "thus for Descartes basic knowledge is always an infallible belief in an indubitable truth" (Sosa, 1980, p. 4).

Thought is thus discovered as the inseparable and necessary attribute of the subject, so it can be defined as thing that thinks or res cogitans (Meditations, II, pp. 27-28), i.e. "thing that doubts, understands, affirms, denies, is willing, is unwilling, and also imagines and has sensory perceptions" (ibid., p. 28). However, the problem of certainty of knowledge still remains, as knowledge cannot consists solely in one knowing self, but it requires object outside of the self. Thus a sort of 'epistemological gap' between the certainty of the self and the certainty about things that appear to us still remains (ibid., II, p. 29; III, p. 42). This problem is going to be solved by Descartes in the next phase of his meditations.

After establishing his firm epistemological point, Descartes re-questions contents of the thinking self. The content he calls 'ideas' and he classifies them, by following his inner experience, into innate (derived from the nature of the subject), adventitious (those that seemingly are coming from the outer world), and invented by the subject (those created by imagination) (ibid., III, p. 38). However, within the content of our thought there is very special idea, which cannot caused neither by the subject nor the possible observable object; that is the idea of God. Descartes elaborates on this point as follows:

"On the other hand who would doubt that he lives, remembers, understands, wills, thinks, knows, and judges? For even if he doubts, he lives; if he doubts, he remembers why he doubts; if he doubts, he understands that he doubts; if he doubts, he wishes to be certain; if he doubts, he thinks; if he doubts, he knows that he does not know; if he doubts, he judges that he ought not to consent rashly. Whoever then doubts about anything else ought never to doubt about all of these; for if they were not, he would be unable to doubt about anything at all" (On the Trinity, X, 10, (14)).

Also, in On Free Choice of the Will:

"Therefore, to start at the beginning with the most obvious, I will ask you first whether you yourself exist. Are you, perhaps, afraid that you are being deceived by my questioning? But if you did not exist, it would be impossible for you to be deceived" $(1964, p .40)$

${ }^{3}$ As it is, for example, questioned by Santayana in Scepticism and Animal Faith (p. 279). 


\begin{abstract}
"By the word 'God' I understand a substance that is infinite, eternal, immutable, independent, supremely intelligent, supremely powerful, and which created both myself and everything else (if anything else there be) that exists. All these attributes are such that, the more carefully I concentrate on them, the less possible it seems that they could have originated from me alone. So from what has been said it must be concluded that God necessarily exists" (Meditations, III, p. 45).
\end{abstract}

In other words, it is very indicative that the imperfect doubting 'self' can have any conception about perfection and infinity (Meditations, III, p. 45; Discourse; pp. 3334). The only way to explain this phenomenon, according to Descartes, is to admit that this idea of the perfect being is put, or impressed, into our mind by that being (Meditations, III, p. 46; Discourse, pp. 34-36). The idea of God, or of perfection, is the most clear and distinct idea (Meditations, III, p. 46), that implies only pure actuality, and nothing that is potential (ibid., p. 47), so that "nothing more perfect than God, or even as perfect, can be thought of or imagined" (ibid., p. 48). This idea is, according to Descartes, so evident and clear that it implies existence, hence the proof for the existence of God is so perfectly established that this truth is "at least as certain as any geometrical proof" (Discourse, p. 36), and much more evident than any knowledge that is in any way connected with the senses (ibid., p. 37). After the existence of God has been established, Descartes shortly elaborates in a typical scholastic way that this meaning implies the main Divine attributes: that it is the first cause of all being (Meditations, III, pp. 49-50), that this very meaning implies its unity, the simplicity, and inseparability (ibid., p. 50), as well as that it has to be some sort of intellectual being as it is the cause of our intellect (ibid., p. 51).

Once God's existence is proven, and the main Divine attributes deduced, it becomes clear that such perfect being cannot be a deceiver (Meditations, IV, p. 53; Discourse, p. 38), hence whatever is grasped clearly and distinctively as true, must indeed be true (Meditations, IV, p. 62; VI, p. 72; Discourse, p. 38; p. 41; Principles, 24), so the error in our knowledge appears only when we do not adequately draw conclusions from the clear and distinctive truths (Meditations, IV, p. 62; VI, p. 72; pp. 79-80; p. 90; Discourse, p. 38; p. 41; Principles, 29, 33).

In any case, Descartes' conclusion is that the only guarantee for certainty is God's existence:

"I have perceived that God exists, and at the same time I have understood that everything else depends on him, and that he is no deceiver; and I 
have drawn the conclusion that everything which I clearly and distinctly perceive is of necessity true" (Meditations, V, p. 70)

"Thus I see plainly that the certainty and truth of all knowledge depends uniquely on my awareness of the true God, to such an extent that I was incapable of perfect knowledge about anything else until I became aware of him. And now it is possible for me to achieve full and certain knowledge of countless matters, both concerning God himself and other things whose nature is intellectual, and also concerning the whole of that corporeal nature which is the subject-matter of pure mathematics" (ibid., p. 71)

"Once the knowledge of God and the soul has made us certain of this rule, it is easy to recognize that the things we imagine in dreams should in no way make us doubt the truth of the thoughts we have when awake" (Discourse, p. 39)

Although it seems Descartes' main goal in Meditations was to justify his physics (Sorell, 1987, pp. 56-57; Hatfield, 2014, pp. 3-4; pp. 20-24), the proof for the existence of God certainly has a central role in his metaphysical system, as this is the only way for bridging the philosophical gap between the self and the objective world. In this sense Descartes' metaphysics can be characterised as 'theistic metaphysics,' that is dominated by themes typical for medieval philosophical theology. ${ }^{4}$ Despite this, Descartes' ideas certainly opened ways for quite different approaches to philosophical problems. Most importantly, caused by his systematic epistemological doubt ${ }^{5}$ Descartes eventually established the strict division between the mind and the world in such manner that epistemology now have primacy over metaphysics, i.e. metaphysics is established on the epistemological starting point instead of on the ontological (like for example in Avicenna, Aquinas and Scotus ${ }^{6}$ ). This division led him to redefine Aristotelian substance: if substance is what subsists in itself, there can be only three substances in one sense, and only one in another sense. Univocally speaking only God is substance, yet equivocally, the

\footnotetext{
4 This interpretation I elaborated more in detail in the article Dekartova teistička metafizika (Descartes' Theistic Metaphysics), Sophos, Sarajevo, No. 11, 2018.

${ }^{5}$ And this is the most important distinction in approach between Descartes and Augustine, as the great Christian theologian merely mentions the impossibility of doubting self-existence, without developing a sufficiently systematic philosophical viewpoint on that foundation.

${ }^{6}$ More on the foundations of medieval metaphysics in Bertolacci, Amos, Establishing the Science of Metaphysics, in The Routledge Companion to Islamic Philosophy, ed. Richard C. Taylor and Luis Xavier Lopez-Farjeat, Routledge, London and New York, 2016, pp. 185-197.
} 
perspective Descartes prefers, substances are three: God, thinking thing (res cogitans), and extensive thing (res extensa) (Principles, 51-54). The division between res cogitans and res extensa is evident if we examine the main attribute of the self and what is the common attribute of everything that we perceive (with our sense perception or in our imagination): subject it thing that thinks, and that is its essence, while the distinctive attribute of the world is that all things in it share the attribute of extension (Meditations, III, pp. 44-45; VI, 79). In addition, Descartes underlines the distinction between attributes and modes of the substance, stating that the meaning of 'mode' is used "when we are thinking of a substance as being affected or modified," while the attribute is the more general (or essential) manifestation of the substance, with the concluding remarks on this point stating that "we do not, strictly speaking, say that there are modes or qualities in God, but simply attributes, since in the case of God, any variation is unintelligible (Principles, 57).

As we are about to see, Baruch Spinoza is going to consequently develop Cartesian position of mainly two foundations: Descartes' metaphysical centrality of God, as well as his understanding of substance, attributes and modes.

\section{Understanding Spinoza's Principles}

Spinoza establishes his metaphysical system on Cartesian reasoning while attempting to follow a strict mathematical analytical precision. Thus we could say that he not just attempts to develop Cartesian philosophy, but also to improve it. This development Spinoza establishes on strictly formulated definitions and axioms. For him, proper or the true definition of a thing shows the exact nature of the thing defined; like the nature of the thing, the definition can contain the cause of existence of that thing, otherwise the cause has to be simply postulated, as every particular existent has a cause, or 'the reason why' (Ethics, pp. 183-184).

His Ethics is established on eight definitions and seven axioms, from which later propositions are precisely deduced:

"Definitions:

I. By that which is self-caused, I mean that of which the essence involves existence, or that of which the nature is only conceivable as existent.

II. A thing is called finite after its kind, when it can be limited by another thing of the same nature; for instance, a body is called finite because we always conceive another greater body. So, also, a thought is limited by 
another thought, but a body is not limited by thought, nor a thought by body.

III. By substance, I mean that which is in itself, and is conceived through itself: in other words, that of which a conception can be formed independently of any other conception.

IV. By attribute, I mean that which the intellect perceives as constituting the essence of substance. V. By mode, I mean the modifications of substance, or that which exists in, and is conceived through, something other than itself.

VI. By God, I mean a being absolutely infinite-that is, a substance consisting in infinite attributes, of which each expresses eternal and infinite essentiality. Explanation.-1 say absolutely infinite, not infinite after its kind: for, of a thing infinite only after its kind, infinite attributes may be denied; but that which is absolutely infinite, contains in its essence whatever expresses reality, and involves no negation.

VII. That thing is called free, which exists solely by the necessity of its own nature, and of which the action is determined by itself alone. On the other hand, that thing is necessary, or rather constrained, which is determined by something external to itself to a fixed and definite method of existence or action.

VIII. By eternity, I mean existence itself, in so far as it is conceived necessarily to follow solely from the definition of that which is eternal. Explanation.-Existence of this kind is conceived as an eternal truth, like the essence of a thing, and, therefore, cannot be explained by means of continuance or time, though continuance may be conceived without a beginning or end.

Axioms:

I. Everything which exists, exists either in itself or in something else.

II. That which cannot be conceived through anything else must be conceived through itself.

III. From a given definite cause an effect necessarily follows; and, on the other band, if no definite cause be granted, it is impossible that an effect can follow. 
IV. The knowledge of an effect depends on and involves the knowledge of a cause.

V. Things which have nothing in common cannot be understood, the one by means of the other; the conception of one does not involve the conception of the other.

VI. A true idea must correspond with its ideate or object.

VII. If a thing can be conceived as non-existing, its essence does not involve existence." (ibid., pp. 179-180)

Spinoza' definitions and their implications must be understood from the perspective of his axioms.

If we keep in mind the axioms, we can elaborate his definitions. As we can see, Spinoza's starting point is the notion of 'self-caused,' which implies that the existence of such being essentially belongs to it. At this very starting point we can see that in the most general sense Spinoza intends to speak about things in two most fundamental manners: something that exists essentially and something that does not exist essentially. The second definition implies the division between finite and infinite; while finitude means the sort of limitation (in every possible sense), infinite is clearly something that cannot be limited in any way. The third definition determines the meaning of 'substance:' 'that which is in itself, and is conceived through itself" - this is the basis of our positive knowledge about the world; the very consideration of a substance shows that it is something independent, on which other things depend. As conceived, substance is intelligible and self-explanatory (Della Rocca, 2002, p. 12). Substance manifests itself through its attribute, which is something that essentially belongs to it; in another words, attribute is the manifestation of the substance's essence. What depend on the substance are mods; they exist because of the substance, and are conceived through the substance. The sixth definition is that of the meaning of 'God:' God is the infinite being. As being in order to be something concrete must be a substance, i.e. that which is in itself, God is substance. As infinite cannot be limited in any way, it cannot be limited by the number of attributes, so God is "a substance consisting in infinite attributes, of which each expresses eternal and infinite essentiality" (the point within this definition is further elaborated within Proposition XIX). The seventh definition shows that freedom means to necessitate; to be free means to "exists solely by the 
necessity of its own nature, and of which the action is determined by itself alone," while not to be free means to be necessitated, it means to be constrained, determined by something other than itself (this is further argued under Proposition XVII). This implies that something like free will cannot exist. 'Free will' is in fact contradictio in adjecto: something is either free or has will, freedom means to necessitate things from itself by itself, while will is something upon which something else can act - it is something determined (Ethics, Prop. XXXII). In this sense, according to Spinoza, there cannot be will in God, while God remains free in the sense of perfection: he necessitates being from himself (as argued in Prop. XVII and XXXIII). Lastly, eternity means 'existence itself;' as it is intuitively evident that in order for something to exist, something else has to exist and so on (whether we accept an infinite chain of causes or the existence of the first cause), as from nothing nothing proceeds, existence must be eternal - i.e. the meaning of 'existence' implies eternity.

As attributes reflect an essence of a substance, it also represents its identity, therefore "two substances, whose attributes are different, have nothing in common," hence the conception of one substance does not imply the conception of other (ibid., Prop. II), and the difference between substances are reflected either by the difference of their attributes or by the difference of their modes (ibid., Prop. IV). This is important as the apprehension reflect the causal relationship between things, and if one thing can be apprehended by the means of the other only if they have something in common it follows that they are somehow causally connected; therefore, "things which have nothing in common cannot be one the cause of the other" (ibid., Prop. III).

So far Spinoza is very precise in his account, which in Proposition V of the First Book of Ethics he develops as follows: "there cannot exist in the universe two or more substances having the same nature or attribute". This is so, Spinoza claims, because there cannot be two substances with an identical attribute (Proof Prop. V), which implies that two things cannot have common essence. Why the essence of substances cannot be the same for the same species of the substances, as in Aristotle? The answer is that Spinoza's substance is not an Aristotelian substance, but Cartesian substance, with one modification - Spinoza's substance can have more than one attribute (Della Rocca, 2011, pp. 22-23). If we accept the distinction between res cogitans and res extensa, which is according to Spinoza already proven by Descartes, it would seem that there are three substances: God, thing that thinks and extended thing; primary attribute of the first is perfection, of the second that is thinking and of the third extension. Yet 'substance' in both Descartes and Spinoza 
means "what exists by itself," the difference is that Descartes takes the meaning equivocally (Principles, 51), while Spinoza thinks about substance univocally. However, if God is the infinite absolute substance, he poses an infinite number of attributes, i.e. his essence encompasses all possible attributes, as the explanation to the definition VI suggests: "that which is absolutely infinite, contains in its essence whatever expresses reality, and involves no negation." This means that if we would assume the existence of two gods, both would be absolute beings and both meanings would encompass all possible attributes without possibility of negation, hence due to their absoluteness and the sameness of attributes they would be in fact be one substance. Therefore, I believe, Spinoza's argument here would be much stronger and better structured upon his definitions and axioms if he, instead of arguing for the existence of only one substance on the basis of the meaning of 'attribute,' argued on the basis of his definitions of God, infinity and existence. If God is the absolute infinite being, and if his essence is his existence (as argued under Proposition XX), then the absoluteness of existence is in fact the absoluteness of the Divine existence. This formulation, I believe, improves Spinoza's argument. This set of arguments is implied in Spinoza's proof on Proposition VI: "if substance be produced by an external cause, the knowledge of it would depend on the knowledge of its cause, and it would itself not be substance," i.e. the axiom IV and the definition III would be compromised. Therefore, that 'one substance cannot be produced by another substance' should be shown before Proposition V.

What follows from the arguments above is that there is only one substance and its existence is its essence or nature (Ethics, Prop. VII). Another argument is that existence is implied by the nature of substance, so it must be included in the substance's definition, but the definition cannot infer the existence of several substances (as the definition cannot contain the reason why there are several of them), thus there can be only one substance of the same nature (ibid., p. 184). This means that any consideration of various attributes, no matter how distinct they are, is in fact the consideration of the one same infinite substance (ibid., Prop. X, p. 185).

\section{Spinoza's Pantheist Epistemology}

Now it is clear why according to Spinoza "besides God no substance can be granted or conceived" (ibid., Prop. XIV), and "whatsoever is, is in God, and without God nothing can be, or be conceived" (ibid., Prop. XV), as all things are in God (ibid., Prop. XVII). This means that God causes all things as the one immanent cause that resemble the immanent causality of logical antecedent and consequent (Curley, 1969, pp. 50-54; pp. 93-94). If all beings are modes of God, their true natures can be 
grasped only through this realisation as the modes of logic resemble modes of existence; God implies his infinite modes, and with it what we call 'the world'.

Metaphysics starts from certain considerations, and the very consideration of the Divine essence is the proof for his existence; also, if one would wish to show that there is no God, he/she would have to prove that God's existence is impossible, i.e. that the meaning of 'God' contains contradiction (Ethics, Prop. XI). However, as "the more reality or being a thing has, the greater the number of its attributes" (ibid., Prop. IX), the infinity of being implies the infinity of its manifestations, hence the ultimate substance must be the all-encompassing-being. Also, the absolutely perfect substance must be indivisible, as division implies that it parts would either retain the absolutely infinite nature and we would have two infinite substances, or its infinity would cease to exist - both options are absurd (ibid., Prop. XIII).

Spinoza's pantheism, as well as his epistemology, is thus established on the Cartesian notion of substance, but on its univocal understanding - 'substance' means 'God'. This is the path Descartes certainly intended to avoid (Ariew, 2014, p. 117). As the result, Spinoza sees two Divine attributes intellect and will as the modifications, while the extension is the attribute. If substance is absolute, one, indivisible, non-composed, and as infinite contains all attributes, this includes extension, so what appear as parts are merely modifications of the substance (Ethics, Prop. XIII, p. 191): "matter is everywhere the same, that its parts are not distinguishable, except in so far as we conceive matter as diversely modified, whence its parts are distinguished, not really, but modally" (ibid., p. 192). At this point we could distinct two interpretation of Spinoza: that his philosophy is deist materialism and that his metaphysical ideas resemble theistic reasoning. It might seem that Spinoza's understanding of God is closer to deism than to scholastic or Descartes' theistic view. Nevertheless, although Spinoza denies intellect as the attribute of God, he still (I believe) sees God in a sense as intellectual being. He claims that "from the necessity of the Divine nature must follow an infinite number of things, in infinite ways-that is, all things which can fall within the sphere of infinite intellect;" as from the infinity of the Divine essence an infinite number of things follow, God is the ultimate efficient cause of all being, or "the efficient cause of all that can fall within the sphere of an infinite intellect" (ibid., Prop. XVI). What is the sphere of an infinite intellect? Spinoza clearly says that "neither intellect nor will appertain to God's nature" (ibid., p. 194). But this is not exclusively so, as Spinoza allows an important condition:

"if intellect and will appertain to the eternal essence of God, we must take these words in some significations quite different from those they usually 
bear. For intellect and will, which should constitute the essence of God, would perforce be as far apart as the poles from the human intellect and will, in fact, would have nothing in common with them but the name; there would be about as much correspondence between the two as there is between the Dog, the heavenly constellation, and a dog, an animal that barks." (ibid., p. 196)

This idea is not as far from Scholastic view as some would think; in the sense of the absolute thought, Divine intellect causes, i.e. necessitates all things, while human intellect is affected by its object (ibid.). Spinoza confirms his agreement with scholastics by saying "this seems to have been recognized by those who have asserted, that God's intellect, God's will, and God's power, are one and the same" (ibid.). What Spinoza disagrees with is that God is to be worshiped in a traditional manner. Therefore, although God, according to Spinoza, has no intellect nor will, this does not mean that Spinoza is materialist; will and intellect are a particular modes of thinking, and God is thinking: "By the intellect we do not (obviously) mean absolute thought, but only a certain mode of thinking" (Prop. XXXI, Proof) - so the absolute thought is God's attribute, while intellect and will are its modifications. ${ }^{7}$

God is the efficient cause of both essence and existence of things, hence essences can only be conceived through God. This assertion reflects the core of his epistemology and metaphysics: "individual things are nothing but modifications of the attributes of God, or modes by which the attributes of God are expressed in a fixed and definite manner" (ibid., Prop. XXV). Spinoza's explanation comes in the note to Proposition XXIX:

"I wish here to explain, what we should understand by nature viewed as active (natura naturans), and nature viewed as passive (natura

\footnotetext{
7 This view is in fact in accordance with medieval Christian and Islamic philosophical teaching, and does not represent something radically new in history of philosophy; God has intellect and will that are incomparable with human's intellect and will, so we are referring to these attributes by these notions merely because we do not have any better notions. The main difference between Christian view and Spinoza is, of course, the creation ex nihilo doctrine. Still, Islamic philosophers (especially Al-Farabi and Avicenna) taught the eternity of the world - the world necessitates from God as emanation as the result of his absolute nature. That Spinoza was familiar with this idea, and actually inspired by medieval philosophers, is clearly indicated by this quotation from his Ethics:

"all the philosophers whom I have read admit that God's intellect is entirely actual, and not at all potential; as they also admit that God's intellect, and God's will, and God's essence are identical, it follows that, if God had had a different actual intellect and a different will, his essence would also have been different; and thus, as I concluded at first, if things had been brought into being by God in a different way from that which has obtained, God's intellect and will, that is (as is admitted) his essence would perforce have been different, which is absurd." (pp. 206-207)
} 
naturata)... ...by nature viewed as active we should understand that which is in itself, and is conceived through itself, or those attributes of substance, which express eternal and infinite essence, in other words... ...God, in so far as he is considered as a free cause. By nature viewed as passive I understand all that which follows from the necessity of the nature of God, or of any of the attributes of God, that is, all the modes of the attributes of God, in so far as they are considered as things which are in God, and which without God cannot exist or be conceived" (Prop. XXIX, Note).

Therefore, God necessarily exists, and through this realisation the certainty about the world is attained; all being necessitates from his nature; all things are in God, and depend on him - in this sense the world is in God and God is immanent in the world (Petronijević, 1982, p. 182). This is Spinoza's main point of departure from Descartes, but also from any scholastic influence. In Descartes' view, God that can be comprehended is not God (Beyssade, 2006, p. 187). In any case, without God nothing cannot exist nor be conceived, and "lastly, that all things are predetermined by God, not through his free will or absolute fiat, but from the very nature of God or infinite power" (Appendix, p. 209). As the Substance is absolute and indivisible, it encompasses nature of everything that is. In this sense God is nature (Deus sive Natura), and every observable nature can be correctly comprehended only as a mode of God's intelligible attribute: a mode that belongs to thought, or a mode that belongs to extension. Metaphysically, the world as the totality of all existing things can be explained only through the doctrine of unity of being elaborated by the main Cartesian notions of substance, attributes and modes.

\section{Conclusion}

As we can see Spinoza's metaphysics is not different only in its content, but also in its epistemological approach. Spinoza adopts Descartes' method, yet once the methodological doubt is surpassed we can re-establish metaphysical science from ontology, like scholastics did it, only with certain improvements on the trace of Cartesian methodology and analytical reasoning. Descartes establish a new model for theistic metaphysics, and this model is based on conception of substance rather than being or existent (ens) and existence (esse) like in Scholastics. This conception follows from his epistemological approach to what is 'clear' and 'distinctive', to what is certain, as well as to the epistemological importance of God as the ultimate substance. Spinoza uses this as leverage for his pantheistic metaphysical system. 
In any case, the epistemological importance of God is the same as in Descartes; all certainty is grasped through the comprehension of the perfect substance; that is clear as the Substance is the foundation of our positive knowledge about the world. Yet this have an important consequence in Spinoza, if we are going to talk about substance in a meaningful way we have to talk about it univocally, and thus there can be only one substance. But this is also the case in the epistemological context; if certainty depends on our conception of the Divine substance, then merely this substance as concept represents the foundation of all our knowledge - only one thing really subsist both in reality as well as in conception. Pantheism thus is not only an interpretation of the world, but metaphysics in which the fundamental laws of logic fully correspond with the ultimate foundation of reality. Thus Spinoza's pantheism represents a way of metaphysical unity of logic and ontology.

\section{References}

Descartes, R. (1985). "Discourse on the Method", In Cottingham, J., Stoothoff, R., Murdoch, D. (eds.) The Philosophical Writings of Descartes, Vol. I. Cambridge: Cambridge University Press, pp.111-177.

Descartes, R. (1985). "Principles of Philosophy", In Cottingham, J., Stoothoff, R., Murdoch, D. (eds.) The Philosophical Writings of Descartes, Vol. I. Cambridge: Cambridge University Press, pp.177-293.

Descartes, R. (1984). "Meditations on First Philosophy", In Cottingham, J., Stoothoff, R., Murdoch, D. (eds.) The Philosophical Writings of Descartes, Vol. II. Cambridge: Cambridge University Press, pp.1-63.

Spinoza, B. (1960). Ethics. In: The Rationalists. Doubleday : Anchor Books.

Spinoza, B. (1970). Etika. Beograd: Kultura.

Ariew, R. (2014). Descartes and the First Cartesians. Oxford: Oxford University Press.

Augustinus, A. (auth.), Matthews, G.B.(edit.) (2002). On the Trinity, books 8-15, tranls. by Stephen McKenna. Cambridge: Cambridge University Press.

Augustinus, A. (auth.), Benjamin, A. S. and Hackstaff, I. H. (transl.). (1964). On Free Choice of the Will, trans, Indianapolis. 
Augustinus, A. (auth.), Ladan, T. (transl.) (1982). De Civitate Dei. Zagreb: Kršćanska Sadašnjost, (Latin and Croatian text).

Beyssade, J.-M. (2006). "The Idea of God and the Proofs of His Existence", In Cottingham, J. (ed.) The Cambridge Companion to Descartes. Cambridge: Cambridge University Press, pp.174-200.

Bertolacci, A. (2016). "Establishing the Science of Metaphysics", In Taylor R. C. and Lopez-Farjeat, L. X. (eds.) The Routledge Companion to Islamic Philosophy. London and New York: Routledge, pp.185-197.

Curley, E. (1969). Spinoza's Metaphysics. Cambridge, Mass.: Harvard University Press.

Della Rocca, M. (2011). "Explaining Explanation and the Multiplicity of Attributes in Spinoza", In Hampe, M., Renz, U., Schnepf, R. (eds.) Spinoza's Ethics A Collective Commentary, Boston: Brill, Leiden, pp. 17-37.

Della Rocca, M. (2002). "Spinoza's Substance Monism", In Koistinen. O. and Biro, J. (eds.) Spinoza; Metaphysical Themes. Oxford, New York: Oxford University Press, pp.11-38.

Hatfield, G. (2014). The Routledge Guidebook to Descartes' Meditations. London and New York: Routledge.

Petronijević, B. (1982). Istorija novije filozofije (History of Modern Philosophy), Beograd: Nolit.

Santayana, G.(1974). Skepticizam i animalna vjera (Scepticism and Animal Faith), trans. Matej Mužina. Zagreb: Naprijed.

Šajković, R. (1970). Filozofija Baruha De Spinoze (Philosophy of Baruch De Spinoza), In: Spinoza, Etika, transl. Ksenija Atanasijević, Beograd: Kultura.

Sorell, T. (1987). Descartes. Oxford and New York: Oxford University Press.

Sosa, E. (1980). "The Raft and the Pyramid: Coherence versus Foundations in the Theory of Knowledge ", Midwest Studies in Philosophy, 5 (1). 